\title{
Electronic and informatization of the judiciary as a tool for innovation
}

\author{
Jaroslav Klátik ${ }^{1, *}$, and Martin Orviský \\ ${ }^{1}$ University of Matej Bel in Banská Bystrica, Faculty of Penal Law, Criminology, Criminalistics and \\ Forensic Sciences, Komenského 20, 97401 Banská Bystrica, Slovakia
}

\begin{abstract}
.
Research background: The computerization and computerization of the judiciary are important support tools with great potential in addressing key issues in the judiciary. The basic architecture of the modernization and informatization of justice consists of the Electronic Judicial File, Development of Electronic Judicial Services, Electronic monitoring of offenders and the Register of Bankruptcies projects. In terms of scope and financial volume, the most intensive electronicization of Slovak courts in their modern history is currently underway. At present, an electronic person monitoring system is also being successfully implemented in Slovakia, which represents a fundamental modernization of prisons, but also an increase in the safety of citizens against perpetrators of violent crimes, domestic violence or crime at public mass events.

Purpose of the article: The main goal of the paper is to analyze the problems in the electronic justice system with a focus on the issue of introducing electronic monitoring of offenders. The authors also analyzes whether a change in legislation that allowed the use of electronic monitoring in more serious crimes contributed to more frequent use of electronic monitoring, or this change did not bring the desired effect of greater use of electronic monitoring.

Methods: The authors use the method of analysis, synthesis, systemstructural method and normative-legal method of interpretation of legal norms.

Findings \& Value added: The main benefit of the research is to point out specific problems in connection with the electrification of the judiciary and the introduction of electronic monitoring and to propose solutions to these problems.
\end{abstract}

Keywords: Electronicization; Execution of a sentence; Electronic court file; Electronic services; Electronic monitoring

JEL Classification: $K 00 ; K 14 ; K 40$

${ }^{*}$ Corresponding author: jaroslav.klatik@,umb.sk 


\section{Research background}

Approximately 112 million euros have been invested in information and communication technologies in the judiciary in the last five years, mainly from EU funds. However, the situation needs to be seen critically, as a lot of money has been invested, but the practical, expected and intended result has not been achieved at this stage. For this reason, we decided in our paper to focus on the use of e-services in the Slovak judiciary, electronic justice and also focus on the possible use of these services in criminal law. The Ministry of Justice of the Slovak Republic has already launched the Electronic Collection of Laws (SLOV-LEX), as well as the Electronic Monitoring of Accused and Convicted Persons (ESMO) project. The Legal Information Portal, Development of Electronic Judicial Services, Bankruptcy Register funded by OPIS, as well as the Electronic Judicial File project funded by the Swiss Financial Mechanism were completed. The electronic administration of the judiciary will continue in the next years, while the projects Centralized System of Judicial Management, Effective Probation and Mediation Service, Support for Effective Management of the Judiciary and the project of a new Business Register should be implemented. In the following years, projects financed from the Operational Program Effective Public Administration were to be added to the eJustice projects. These were to support the optimization of processes, the training of judges and judicial staff, the improvement of the analytical capacity of the Ministry of Justice and the expansion of support for the activities of the Legal Aid Center. The parties will be able to view the court file online, the courts will be able to hear it by videoconference and the publication of court decisions on the web will be improved. These are just a few of the several benefits that the Development of Electronic Judicial Services Development Project ("RESS") will bring to the courts. The project financed from the funds of the Operational Program Informatisation of Society is beginning to be implemented thanks to the contracts signed by the Ministry of Justice of the Slovak Republic (hereinafter also "MS SR") with a certain period of time with three suppliers. The Ministry of Justice of the Slovak Republic places emphasis on increasing the responsibility of judges for the proper performance of their profession, and on the other hand does everything it can to equip courts with new technologies and to make their work more efficient and faster. The electronicization of courts is considered an important pillar of the overall planned reform of the procedural environment, which will bring citizens and businesses more modern rules for the protection of their rights. In terms of scope and financial volume, the most intensive electronicization of Slovak courts in their modern history is currently underway. The basic architecture of the modernization of electronic justice equipment consists of projects that are implemented with leading suppliers in the field of information technology, who are already implementing several projects, such as the implementation of electronic court file (financed by the Swiss mechanism) or electronic Collection of Laws - Slov-Lex. financed from Eurofunds. In addition to faster and more efficient court proceedings, it will make an important contribution to the transparency of court decisions, thanks to improvements in the system for publishing court decisions on the Internet, which is currently not fully compliant. The RESS project also includes an extensive complex of interconnected services. These include, for example, the completion of the services of the eŽaloby portal, the construction of InfoSúd services (informing the participant about the status of proceedings, informing about hearings and information on court proceedings in various court agendas, information on the official bulletin board), developing an electronic expert diary building a module of electronic judicial statistics and departmental reporting, building a Universal Secure Repository of the Judiciary (archive) and, of course, the mentioned services in the field of videoconferencing. The implementation of the RESS project will make available, resp. improve electronic access for the public and institutions in the area covering the ten 
agendas of public administration, which are related to at least sixteen life situations of citizens and entrepreneurs. Electronic services will use the basic registers of state administration as well as registers under the responsibility of the ministry and will become an integral part of electronic public administration services. The project complemented the ongoing informatization of justice in Slovakia and will build on the project Development and Technical Innovation of the Judiciary (RTIS). Although on the outside it seems that the electronicization of justice is and will be mainly concerned with civil law, this is not the case. In criminal law at present, electronic monitoring of persons is in practice, which represents a fundamental modernization of prisons, but also an increase in the safety of citizens against perpetrators of violent crimes, domestic violence or crime at public mass events (especially in stadiums). As for an overview of the current state of other eJustice projects, it is the project Development of electronic services of the judiciary, the project Modernization of court operation, the project Electronic court file - keeping the court file throughout its life cycle in electronic form, creating an effective tool for streamlining processes in the judiciary. The project is funded by the Swiss-Slovak Cooperation Program; Electronic Personnel Monitoring System project, SLOV - LEX project, Development of the Commercial Register, Project Register of Legal Entities.

\section{Development of electronic services in the judiciary}

At present, the development of electronic justice services (RESS) is often discussed at the professional level. The main goal of the RESS project is the development of existing and introduction of new electronic services and the judiciary, taking into account the construction of integration interfaces MS MS, courts and the Central Public Administration Portal (hereinafter "IPO"), universal secure and trustworthy repository videoconferencing infrastructures for the department's information systems, which provide electronic services for citizens, businesses and public authorities. The partial goals of this project include:

a) electronic services of courts currently in conventional (paper) form,

b) the development of partially electronic services of the judiciary to a more sophisticated level within the existing, resp. created by the IS of the judiciary,

c) introduction of new electronic judicial services and construction of new IS,

d) the deployment of the necessary infrastructure (in particular a secure and trusted repository for all departmental information systems, licenses, judicial videoconferencing system, etc.).

The implementation of the RESS project and its components, the information system of the universal security repository of the judiciary (IS UBÚS) and the videoconferencing system of the Ministry of Justice of the Slovak Republic, as well as related services, will make available, resp. improve electronic access of the public and institutions in the field of 5 sections of public administration (Courts and prisons; Legislation in the field of constitutional law, criminal law, civil law, commercial law, family law, bankruptcy law and private international law); State supervision over activities of the Slovak Chamber of Bailiffs and of the Notary Chamber of the Slovak Republic; State supervision to the extent stipulated by law over the activities of bailiffs and over the activities of notaries. These sections cover 10 public administration agendas related to 16 life situations of citizens and entrepreneurs, the project will cover the electronicization of 10 eGov services and more than 30 IS services. Electronic services will use the basic registers of state administration as well as registers under the responsibility of the ministry and will become an integral part of electronic public administration services. The project will complement the informatization of justice (eJustice) in Slovakia, which takes place within the projects:

a) Development and Technical Innovation of the Judiciary (RTIS) - Phase I Electronic Judicial File (ESS), 
b) Electronic Collection of Laws (SLOVLEX),

c) ESMO - Electronic monitoring services for convicted and accused persons (support and development of the imposition of alternative punishments and related building of technical conditions),

d) RPO - includes the development of ORs, interconnection of functionalities and improvement of the robustness of ORs as a source register for RPO.

The RESS project at the level of the development of electronic court services follows on from the project Development and Technological Innovation of the Judicial-Criminal and Judicial-Civil Agenda (RTIS) of the Ministry of Justice of the Slovak Republic. The RTIS project represents the first stage for the introduction of an electronic court file, which represents a comprehensive IS for the management and administration of the civil and criminal agenda so that the file can be kept throughout its life cycle in full electronic form. As part of this, the implementation of a guaranteed electronic signature (ZEP) at all levels of electronic document management and the change of an outdated technological platform are being prepared. At the same time, it partially addresses the issue of electronic activities of experts, translators and interpreters and the basis for the automation of judicial statistics. Total eligible expenses for project implementation represent amount of 27,179,049.89 EUR. The Development of Electronic Judicial Services (RESS) portal introduces new and develops existing public electronic judicial services using data from existing systems, taking into account the construction of a technical infrastructure for videoconferencing and the construction of a universal secure repository for courts. The main services of the portal are:

- filing of motions to institute legal proceedings and other documents (e-Žaloby portal),

- the provision of information from the electronic court file to the parties to the proceedings,

- $\quad$ an electronic diary for forensic experts, translators and interpreters,

- central record of executions,

- videoconferencing/provision of remote video communication of participants in proceedings, making the course of court proceedings available to remote third parties online, provision of videoconferencing services to the judiciary,

- publication of court decisions and other information (InfoSúd portal),

- provision of information from judicial and judicial statistics,

- providing information from the registers of experts, interpreters, translators, auctioneers, executors, notaries, advocates, mediators, arbitration courts, probation and mediation officers.

The main goal of the project is to build and achieve sustainable development of components of public administration information systems enabling the development of existing e-services to a more sophisticated level and the introduction of new judicial eservices for citizens, entrepreneurs and public authorities through investments in HW, SW and applications. The benefits of the project may include:

- electronic processes of public administration,

- service of electronic documents in the electronic boxes of the parties,

- remote encrypted access for the party to the proceedings to an electronic judicial file,

- remote encrypted access for the relevant court staff to the electronic court file,

- establishing automatic anonymisation and search in court decisions,

- change of the form of communication from "paper" to compulsory electronic between the judge and the notary as judicial commissioner in inheritance proceedings, 
- the obligation to file only in electronic form with a guaranteed electronic signature (ZEP) for all legal entities, for all self-employed persons and for all natural persons represented by a legal representative (lawyer),

- lustrations in all necessary registers,

- increasing the competence of public administration,

- streamlining and increasing the efficiency of public administration,

- increasing the satisfaction of citizens, entrepreneurs and the general public with public administration.

The Ministry of Justice of the Slovak Republic is responsible for the administration and operation of the information system. The Ministry of Justice of the Slovak Republic is the responsible state administration body for courts and prisons, court administration, methodological guidance of development, deployment and use of information systems and technologies in courts. He is also responsible for the administration of the Central IS of Courts (ISS), the direction of departmental archives and the coordination of the processing of state statistics, court statistics and reporting. As part of the development of electronic judicial services, the legislator will seek to achieve the development of existing and the introduction of new electronic judicial services that provide electronic services to citizens, businesses and public authorities. The project aims to meet the objectives of long-term state policy in the field of justice, namely the "open court", eliminating delays in court proceedings and increasing law enforcement, which can be achieved by streamlining the activities and organization of the judiciary and the ministry. This will synergistically contribute to reducing costs related to securing the agendas of these sections of public administration, saving time and increasing the comfort of the provider as well as users of electronic services of the department. These relate to the area of public services of the judiciary (ISS - eŽaloby, ESS and InfoSÚD services), development of the Electronic Expert Diary, construction of the Central Enforcement Register (CEEx) module, construction of the electronic judicial statistics and departmental reporting module, development of the IS videoconferencing services of the judiciary courtroom) and the ISS module - Universal Secure Judicial Repository (Archive). The project may result in new and innovative public administration services provided to citizens online, which will also be accessible to disabled people and other disadvantaged groups.

Other benefits of the implementation of this project include:

- procedurally and technologically significant complement to the solution of the electronic court file,

- resolve the execution agenda not covered by other projects,

- resolved only partially solved electronic collection and processing of departmental statistics of the judiciary,

- ensure the sophistication of information services for the public and the ministry to this level - the ministry, the judiciary and related agendas (experts, executors) supporting state-of-the-art implementation methods (smart requirements),

- complement eServices for the public for evolving RTIS modules,

- provides more support services, completion of internal modules (lustrations, delivery of court documents and decisions of legal entities and individual), central administration of code lists through a binding reference source.

\section{Central portal of public administration}

The Central Public Administration Portal (IPO) provides central and unified access to public administration information sources and services. The information (advice, instructions, descriptions) that are being sought is currently often part of the information 
servers of individual departments. The aim of the portal is to integrate this information and services and provide them to the user in a clear and accessible form. One of the most important tasks of the central portal is to direct the user to the use of a specific electronic service of public administration with the use of relevant information sources. The content of the IPO includes digital content in the form of supporting information for the use of the service and the provision of electronic services. The concept of ÚPVS content is governed by the following principles:

- organization of information and services according to the areas of life situations - in the current "information pressure" it is often difficult to obtain the required and necessary information. For this reason, the services at ÚPVS are logically divided according to the target group (citizen / entrepreneur / institution) and the areas of life situations that make information and services available in alphabetical order. This concept makes it possible to access the required information sources as well as electronic services in a structured manner, according to the actual requirements of the user, and to filter the extensive content of the IPO in a targeted manner. The structuring of the content of the IPO is one of the decisive benefits of the IPO with regard to the distributed resources on the websites of the individual connected entities;

- virtual centralization - from the point of view of users of ÚPVS services, the portal represents a centralized solution, where all information is available from one place and logically divided electronic services are accessible in a uniform way. However, centralization is not realized by transferring services to ÚPVS, it is a virtually centralized system, which represents an integration platform for all other services information resources and systems implementing individual processes. However, the government portal, even with a distributed structure, appears to the user as a centralized system with a unified logic and structure.

The central public administration portal is defined as a public administration information system through which it is possible to centrally perform electronic official communication with any public authority and access common modules, in particular via the Internet pursuant to Act no. 305/2013 Coll. on the electronic form of the exercise of powers by public authorities and on the amendment of certain laws (the e-Government Act). The administrator of the central portal is the Office of the Government of the Slovak Republic. The Central Portal is operated by the National Agency for Network and Electronic Services (hereinafter "NASES"). NASES is a contributory organization of the Office of the Government of the Slovak Republic, which is established for the purpose of fulfilling the tasks of the Office of the Government of the Slovak Republic arising from $\S 24$ par. 3 of Act no. 575/2001 Coll. on the organization of government activities and the organization of the central state administration, as well as $\S 4$ a of Act no. 275/2006 Coll. on public administration information systems. It is mainly the fulfillment of professional tasks in the field of informatization of society, administration and operation of electronic communication networks and services for the Office of the Government of the Slovak Republic.

Key competencies of NASES:

- operation and development of the GOVNET network,

- $\quad$ sTESTA operation for the Slovak Republic

- operation and development of the Central Public Administration Portal,

- development of broadband internet infrastructure,

- advisory, consulting, brokerage and training activities in the field of informatics, information networks, electronic communication networks, computer technology.

The activities of NASES maximally support the acceleration of the development and expansion of e-Government services in Slovakia, which should lead to savings and streamlining of public administration, simplification of citizens' contact with authorities, as 
well as support of the overall information maturity of Slovak society, public sphere, business community, as well as the general public. The Act on e-Government aimed to establish general legal regulation of the manner of exercising public power in electronic form, including related legal institutes, and thus enable the implementation of electronic services of public authorities in a uniform manner, without the need to interfere with any specific legislation governing specific cases. this power. The essence of the law is the codification of electronic communication as the main form of communication with the public power and the public power itself among themselves so that communication processes are simplified, accelerated, clarified, unified and to increase the security of this communication. Another important factor is the introduction of completely new institutes (e.g. document conversion, electronic mailboxes), which were missing in the legal environment and are necessary for the proper functioning of electronic processes. The aim is not to replace the existing regulations (especially governing administrative / judicial proceedings), but to establish, so to speak, an electronic alternative to the "paper, paper" method of exercising public power, while maintaining the regulation of this exercise in its details by special regulations.

\section{Electronization in criminal law}

\subsection{Institute of Preliminary Investigation}

The judge or prosecutor may instruct the probation and mediation officer to obtain information on the accused. This information then are used to decide on the appropriateness or unsuitability of imposing an alternative sentence, imposing appropriate restrictions and obligations, also with regard to their enforceability in relation to the personal needs, abilities of the accused or injured party. As part of the preparatory proceedings and court proceedings, the activities of the probation and mediation officer in connection with the agenda of house arrest, the sentence of compulsory labor, but also probation supervision in connection with imposed appropriate restrictions or obligations are focused on the implementation of the so-called institute of preliminary investigation and verification of intervention needs. The institute of preliminary Investigation expands the possibility of the probation and mediation officer working with the accused, the injured party, but also with their social environment, in which they are in the phase before the decision ofcourt. The Probation and Mediation Officer places reasonable emphasis on obtaining relevant knowledge and information about the perpetrator or victim / victim and their social environment, which can serve as a basis for the decision of the judge or prosecutor. Such knowledge and information will create space for a more objective assessment of the appropriateness of imposing a selected prohibition, obligation or restriction, thus eliminating risk factors that may have a negative impact on the enforceability of the decision or compliance with the imposed obligations and restrictions.

The purpose of the implementation of the institute of preliminary investigation is in particular:

- find out basic information about the person of the accused,

- mapping of his current situation (family, social, work, health)

- knowledge of the circumstances of the offense committed in terms of the possible risks and needs of the offender,

- ascertaining the offender's attitude towards the crime committed and the degree of his responsibility for dealing with its consequences,

- clarification of the needs and interests of the victim of the crime (in particular compensation), 
- determination of the degree of risk of recurrence or need for intervention,

- recognition of the appropriateness of imposing a house arrest in a social environment and identification of possible risks preventing the execution of such a sentence, as well as the degree of motivation of the offender to submit to execution if sentenced or appropriate restrictions and obligations in connection with tertiary prevention, resp. recognition of the suitability of the control of the execution of another decision on the imposed prohibition, restriction or obligation by technical means.

\subsection{Electronic monitoring of the accused}

One of the areas of electronic justice and thus the use of the e-service is the use of electronic monitoring of accused and convicted criminals. The use of electronic monitoring is more versatile and can be used in other areas, such as the imposition of a ban on participation in public and sporting events, or in cases of domestic violence as a control of not approaching a certain person. The introduction of electronic monitoring is also important in the use of the institute of conditional release from imprisonment, where such a form of control could have an effect on judges' considerations of the risk of re-failure of convicts, as well as on conditional suspension of criminal prosecution. [2] It is also possible to use control by technical means within the execution of a custodial sentence in institutions for the execution of a custodial sentence while allowing the free movement of convicts outside the institution. Options for the deployment of electronic bracelets can be seen in the conversion of the rest of the custodial sentence into house arrest, as well as in the control of prohibitions for the monitored person to stay at a chosen place or approach another person, and also when replacing custody. While serving a sentence of house arrest, the offender must stay in his home for a period to be determined by the court. Electronic bracelets are used to monitor compliance with this regulation. The system, to the operation of which the convicted person contributes in the amount of EUR 1.50 per day, also makes it possible to remotely check whether the inspected person is not under the influence of alcohol. The Slovak system of electronic bracelets allows monitoring of up to 2,000 people, but it must be said realistically and critically that such a number of monitored persons will probably not be achieved in the Slovak legal environment in the near future. Since the introduction of electronic monitoring, the state has originally promised to free up places in prisons and reduce the cost of prisons, which unfortunately was not achieved. Electronic monitoring is related to the already mentioned project "Electronic Personnel Monitoring System" ESMO, which entered into operation exactly ten years after the entry into force of the new criminal codes. Its main goal was to more strongly enforce the alternative sentence of house arrest, the imposition of which judges have so far avoided. The Slovak Republic purchased 1,000 electronic monitoring bracelets, 500 devices for monitoring using a GPS signal, 250 devices for telephone monitoring, as well as devices for probation and mediation officers. The convict person (if he is sentenced to house arrest) will be able to go to work properly. He will have to stay at home for set hours, which will be monitored by the aforementioned electronic bracelet based on his leg. Another device will monitor his breathing at regular intervals to see if he has consumed alcohol. Electronic monitoring of accused and convicted persons in Slovak conditions as an innovative service can enable more flexible imposition of alternative punishments (e.g. house arrest, monitoring compliance with the ban on approaching another person and location, compliance with specified hours at work, or monitoring the consumption of alcoholic beverages, narcotics substances, etc.). [3]

These sentences are significantly more effective in redressing convicts than placement in prison. The use of e-services will also cover areas such as cases of domestic violence, petty theft, harassment, maladaptive neighborhood behavior, etc. Electronic monitoring can 
be used in principle for all three basic stages of criminal justice, i. j. before the actual judgment on guilt as part of an alternative to imprisonment, after release as part of probation supervision. The real potential of electronic monitoring of convicts will be fully exploited by publishing electronic services that will enable citizens to report violations of the law, the introduction of active services warning of convicts (use for victims of domestic violence, warning vendors of perpetrators of petty theft, etc.) to prevent violent and property crime and, last but not least, the introduction of electronic monitoring of convicts using alternative punishments (eg house arrest, monitoring compliance with the prohibition on approaching another person and location, compliance with designated hours of stay at the workplace, etc.). The implementation of the ESMO project, which started in February 2014, introduced a modern, efficient and integrated information system providing electronic services related to electronic monitoring of accused and convicted persons, serving citizens, entrepreneurs and local governments. Related to this is the effectiveness of Act no. 78/2015 Coll. on the control of the execution of certain decisions by technical means and on the amendment of certain laws. This law is based on Recommendation CM / Rec (2014) 4 of the Committee of Ministers of the Member States on electronic monitoring (adopted by the Committee of Ministers on 19 February 2014 at the 1192nd meeting of the Ministers' Deputies), and may contribute to better application of Act no. 533/2011 Coll. on the recognition and enforcement of decisions imposing a non-custodial criminal sanction or probation measure for the purposes of supervision in the European Union, transposing Council Framework Decision 2008/947 / JHA of 27 November 2008 on the application of the principle of mutual recognition to judgments and probation of the Decision for the purpose of supervising probation measures and alternative sanctions (OJ L 337, 16.12.2008), as amended by Council Framework Decision 2009/299 / JHA of 26 February 2009 (OJ L 081, 27.3.2009).

Act no. 78/2015 Coll. provides that control by technical means may be ordered by a court or a public prosecutor. The performance of the ordered control by technical means will be ensured by a probation and mediation officer in cooperation with the operations center, whose activities will be ensured by the Ministry of Justice, which will also have the technical means used in the administration. In this context, it should be noted that control by technical means is not a sanction mechanism but is a tool for monitoring the enforcement of statutory decisions imposing prohibitions, obligations or restrictions (sanctions). The purpose of the Act is, in connection with the legal regulation contained in the Criminal Codes and in the Code of Civil Procedure, to regulate the detailed procedure of the interested parties in controlling the execution of certain decisions by technical means. The possibility of using technical control over the execution of a decision will be given by the Criminal Codes and the Civil Procedural Code, which will stipulate specific types of decisions, the control of the execution of which can be monitored by technical means. [2] According to the Criminal Code, the Criminal Procedure Code and the Civil Procedure Code, an order to control the execution of a decision by technical means will be possible in those decisions imposing a house arrest sentence or converting a custodial sentence into a house arrest sentence., decisions imposing a residence ban, decisions imposing a ban on participation in public events, decisions imposing protective supervision, provided that appropriate restrictions and obligations are imposed at the same time, the nature of which allows for control by technical means, decisions imposes probation supervision on conditional suspension of a custodial sentence if, at the same time, appropriate restrictions and obligations, the nature of which allows control by technical means, are imposed, a decision imposing probation supervision on conditional release from serving a custodial sentence, if appropriate restrictions are imposed; obligations which $p$ ovaha allows control by technical means, decisions by which the criminal prosecution is suspended, if at the same time appropriate restrictions and obligations, the nature of which allows control by 
technical means, have been imposed, ordering an urgent measure pursuant to $\S 325$ par. 3 of the Civil Procedure Code.

\subsection{Application problems in the context of the use of electronic monitoring of persons}

The introduction of electronic bracelets in prisons has not solved and will probably not solve for a long time the problem of the low rate of imposing alternative punishments for convicts and the insufficient capacity of Slovak prisons. After the start of the project, the system shows a high degree of inefficiency and inefficiency, its basic goals and expected benefits for society are not met. In 2016, the number monitored through the ESMO was only at the level of 25 people, which is $1.25 \%$ of the target 2000 people per year. Of this number, eight perpetrators were sentenced to house arrest. Given the current number of monitored persons and the rate of use of the ESMO, there is a risk of non-compliance with the return on investment, which was quantified at six years in the analysis. The ESMO must therefore be used more frequently to monitor convicted workers outside prisons. The original project budget of 26.7 million euros from Eurofunds corresponding to 2000 monitored persons was increased annually by 358,800 euros from the budget of the Ministry of Justice of the Slovak Republic for hardware and software licenses. The total expenditure thus amounted to EUR 27.3 million. The robustness of the system, already dimensioned in the feasibility study, did not correspond to the real need and possibilities to use the ESMO for the target limit of 2000 persons per year. Failure to use the system to the extent expected will result in a significant increase in the price of the service, the price of which has been set at almost EUR 3.9 million per year. Electronic bracelets are most often used in cases of sentences of house arrest, prohibition of approaching a person, prohibition of entering a designated zone, obligation to remain in a certain zone or in cases of prohibition of drinking alcoholic beverages. The level of imposition of alternative sanctions has not yet changed compared to the period before the implementation of the ESMO.

The project assumed to meet the target limit of 2000 monitored persons per year. The expected benefits of the introduction of the ESMO have not materialized for a number of reasons. In the area of legislation, the adoption of the Act on the Control of the Enforcement of Certain Decisions by Technical Means and the amendment of related legal norms (especially Criminal Code, Criminal Procedure Code, Civil Procedure Code, mediation officials etc.) legislative conditions have been created for the imposition of alternative sentences, including the sentence of house arrest. Due to the fact that they entered into force on 1 January 2016, the real deployment of electronic monitoring could only take place with a certain time lag, of course, due to the time needed for court decisions. Due to the independence and impartiality of judges, which is guaranteed to them by the Constitution of the Slovak Republic, their decision on the imposition of alternative punishments, as well as their participation in training by the Ministry of Justice of the Slovak Republic is difficult to influence. Negatives that affect the use of ESMO include malfunction and insufficient user friendliness of some components of the ESMO system, non-use of some components in the capacity range for which they were designed. The reason for this situation is the time constraint in the implementation phase of the project, which did not allow for a detailed check and test of all functionalities. The real possibilities of the number of convicts who meet the conditions for monitoring in accordance with the relevant laws are also questionable. For example, house arrest can only be imposed for less serious crimes. Capacity could thus relieve the separation of prisons with the lowest degree of guarding, in which the situation is not so critical. Overcrowding is shown mainly by departments with a medium level of guarding. The system, which is designed for 2,000 
monitored persons per year, is not used, while its maintenance and service cost taxpayers more than 3 mil. EUR per year.

\subsection{Electronic criminal report}

From November 2016, a criminal report can also be filed over the Internet without the need to go anywhere. The Electronic Services project of the General Prosecutor's Office of the Slovak Republic enables this to the notifiers through the central public administration portal. Until now, a citizen had to file this criminal report with the police to the prosecutor's office in person or in writing, now he will do so at home, via his computer and an identity card with a chip. Thanks to the new system, the citizen can also request the sending of information concerning the current state of proceedings in a specific matter. However, this does not mean that he will have access to all the details, he is notified only to the extent that it has been announced orally or in writing in the individual acts. The citizen can only file a criminal complaint on his or her own behalf. The form reads from the ID card with the chip the name and surname of the notifier, and this does not change. The citizen's system will also point out that the filing of a criminal report is also subject to possible civil and criminal sanctions in the event of false information. In addition to the possibility of filing an electronic criminal report, the project of electronic services of the prosecutor's office also enables the simplification of access to the extract and extract from the criminal record. This can also be realized through www.slovensko.sk. Unlike filing a criminal report, functionality is subject to a fee. As soon as the fee for the request for an extract or write-off is credited to the prosecutor's office's account, the document is sent to the applicant on this day. In addition to simplifying the agenda for citizens, the electronic services of the General Prosecutor's Office of the Slovak Republic also bring more efficient work for the bodies active in criminal proceedings themselves. Prosecutors may use, for example, an electronic prosecution file, which is the equivalent of a paper civil or criminal file. They will also have a mobile file at their disposal, which they can use in procedural acts, such as in a police detention cell. The system will allow the police or the court to electronically send to the prosecutor's office for processing, for example, a valid court judgment or a report on the course of the execution of a sentence. The new electronic services of the prosecutor's office are part of the Operational Program for Informatisation of Society (OPIS) project. The cost of setting up the services is $€ 13.5$ million and is covered by European Union funds. At the same time, the information system is linked to selected judicial systems of the EU Member States, which will improve international cooperation in the field of justice.

\section{Electronic court file}

The primary goal of the Electronic Judicial File module within the project Development of Electronic Judicial Services - Electronic Judicial Services Information System (RESS - IS ESS) is to make documents kept within the Electronic Judicial File (ESSp) available to users registered within the Electronic Judicial Services portal. This module enables the submission of a request for access to the content of the court file, access to the content of the electronic court file, information on the proceedings and the archive of court recordings, search and viewing records in the ESSp, registration of a document in the ESSp, information on court proceedings and changes in the ESSp. This module is intended for a party to legal proceedings, a legal representative of a party to legal proceedings, a person involved in court proceedings (notary, executor, expert, interpreter, translator, conflict guardian), a third party - the public (primarily for administrative proceedings). To use the services of the module, you need an identity card with a chip (eID) and an eID reader and installed software. Holders of identity cards with a chip with a guaranteed electronic 
signature can do so through a central public administration portal. Project "Development and technological innovation of the judicial-criminal and judicial-civil agenda of the Ministry of Justice of the Slovak Republic", which aims to gradually electronicize the court file and create an effective and efficient information tool for the judiciary in the Slovak Republic, ie a comprehensive information system for administration and management The civil, commercial, administrative and criminal agenda for the courts of the Slovak Republic is financed from the resources of the Swiss Financial Mechanism. This project will significantly contribute to the narrowing of the scope for corruption in the judiciary, strengthen the department institutionally, eliminate significant decentralization of information systems and improve their capacity and permeability in relation to the authorities and citizens concerned. The project consists of the development of a technical, technological and procedural platform on which the judiciary is built towards electronic support of court proceedings. It is based on the functional extension of the currently used software for civil, commercial and administrative judicial agenda of the judicial management information system, which incorporates the functionality of the currently independently and separately operated solution for the criminal judicial agenda. After the unification of the two main supporting software of the judicial criminal agenda and judicial management, a new judicial system will be created, with two functional domains, namely the judicial criminal agenda and the judicial-civil agenda, which will enable registers, code lists and users to be shared. A prerequisite for the development of an information system for courts is, in addition to the development of its functionalities, the transition to new modern technologies. In the output solution, the information system for courts will meet security standards, all data flows will be encrypted and stored in eight central repositories of regional courts, which will bring immediate access and distribution of processed files remotely, thus eliminating copying and transfer of files, documents and other documents in within the courts, e.g. when changing the territorial jurisdiction of the court, changing the legal judge, etc. The system will allow users of forensic management to view the files even by remote access, of course in strict compliance with all security measures. It will also provide a full electronic version of the court file with all its paper annexes. The aim is also to prepare the system for a guaranteed electronic signature at all levels of electronic document management. The main outputs of the project are mainly the construction and deployment of an electronic court file, the basic functionality of the court data repository, the related necessary infrastructure changes, as well as the recording of court hearings, scanning and electronic diary of an expert, interpreter and translator. These developments are aimed in particular at increasing the transparency of court proceedings, increasing access to the file, better acquaintance of court proceedings with the parties, faster form of service of court decisions, reduction of administrative tasks, staffing and support of court staff, elimination of human error in court proceedings and thus support the elimination of any corruption gaps in the existing process. The electronic file will support the reduction of court delays in court proceedings, bring about a faster form of service of court decisions and reduce administrative costs.

\section{Discussion}

It is clear that the basic problems of the judiciary are delays in court proceedings, which directly affect the enforcement of the law, the quality of the decision-making activity of courts and the persuasiveness of court decisions and the instability of the legal order. [1] The causes of these problems are of a different nature and are given both by the socioeconomic development of the Slovak Republic after its establishment (transformation process) and the development of the legal environment in which courts exercise their jurisdiction and actual application of law, which is influenced by various motives. This is 
especially clear in the case of delays in proceedings, which represent the most significant problem of the Slovak judiciary, which is ultimately confirmed not only by public opinion, but also by the decision-making activity of the Constitutional Court of the Slovak Republic and the European Court of Human Rights. The instability of the legal order significantly affects the activity of courts in all directions. This applies in particular to frequent changes in procedural rules, unsystematic interventions in the status of judges (especially in the area of judges' remuneration), changes in the court system (establishment of courts, their subsequent abolition and re-establishment), as well as reckless expansion of courts. legislation, whether of a substantive nature (granting a new right usually leads to a dispute over that right) or of a procedural nature (any new process within the public administration represents a potential increase in the administrative justice agenda). In terms of the impact on the performance of the judiciary, the instability of the legal order is understood not only as frequent and confusing changes in the substantive legislation, but above all as changes directly affecting the judicial system, its organization and operation. A suitable tool for ensuring real and effective access of all to valid legislation is the creation of an information system providing a comfortable overview of valid and effective law, i. j. information system for the provision of binding electronic consolidated texts of legal regulations and other standards to the addressees of the law. Given the improvement and transparency of the legislative and regulatory environment that such an information system will provide, one of the long-term results can be expected significant societal socio-economic benefits in terms of savings and greater efficiency of the economy and the functioning of the state. Taking into account the basic principle of law, that everyone is familiar with valid and effective law and is aware of their rights and obligations, which in practice due to the growing volume and complexity of legal norms is increasingly difficult to apply, the implementation of the intention of electronisation Fulfilling this principle by ensuring real access of all to the valid legislation and enabling a clear and faster orientation in the legal order of the Slovak Republic, will improve and increase the transparency of law-making. The electronic and informatization of the judiciary is an important support tool which, in synergy with the above measures, has great potential in addressing these key issues of the judiciary. The aim of informatization of the judiciary is primarily to create conditions for efficient, modern, accessible and fast court proceedings providing the participant in court proceedings with the convenience of electronic communication, electronic availability to address procedural acts of the court, including external control of proceedings and court decisions, i. j. judicial power promoting the transparency and openness of the judiciary. Within the informatization of the judiciary, it is necessary to focus on several areas. A prerequisite for the successful implementation of all measures of electronic justice and, above all, a prerequisite for the effective use of the results of electronic justice is to ensure the continuous modernization of computer technology in courts to meet the standards of other state institutions. The streamlining, simplification and acceleration of administrative processes in the judiciary when working with the court file will be brought about by the electronic processing of the court file. [1] The main goal of electronic court file is to expand the functionality of court information systems for the management and administration of civil and criminal proceedings with such functionalities that will allow file management throughout its life cycle in electronic form and change the outdated technology platform and creating an effective tool for comprehensive streamlining of processes in the judiciary. Electronic service is another tool for streamlining, simplifying and speeding up administrative processes in the judiciary. Electronic service will make it possible to speed up the service of judicial decisions and documents on the parties to proceedings and to avoid the possibility of avoiding the taking over of judicial consignments. Following the electronic court file and electronic delivery, it is necessary to ensure the development of electronic judicial services - further development of electronic court file functionalities (eg 
electronic expert diary, central execution register, bankruptcy register, disqualification register) and especially the development of judicial services in relation to the public publication of statistical data, remote access to the court file via the Internet, more efficient publication of anonymised court decisions and introduction of videoconferencing technology in court proceedings. An important area of informatization related to the availability and transparency of law and thus also to the stability of the legal order is the creation of the Electronic Collection of Laws (SLOV - LEX). The electronic collection of laws ensures real and effective access for all to applicable law. In order to create technical conditions for increasing the rate of use of the imposition of alternative sanctions, the implementation of the project Electronic Surveillance System for Persons (ESMO). Here, with regard to its full use by up to several years, it is assumed that the costs of operation of detention facilities and the execution of imprisonment will be reduced by creating technical conditions for imposing an alternative sentence of house arrest, resp. other penalties and measures, the effective execution of which is possible with the help of an electronic system for monitoring persons. [2] In order to ensure the full and effective use of the electronic monitoring system of persons, it is necessary that at the same time as the implementation of the information system, the institutional and organizational prerequisites in relation to the probation and mediation service are ensured. For the future, the extension of e-services into criminal law cannot be ruled out as far as possible, but this would mainly concern the technical and organizational provision of criminal proceedings. However, one very important element needs to be made with regard to the computerization of the judiciary, which would make the appointment of lawyers of their own motion clearer, fairer and more transparent, i.e. j. lawyers ex officio, as it is clear that in many district courts, in particular the pre-trial judges and the presidents of the chambers, the same lawyers still receive the same lawyers without any substitution, which in any case does not increase confidence in the criminal justice system.

\section{References}

1. Klátik, J. 2010. Zrýchlenie a zhospodárnenie trestného konania. Banská Bystrica : Právnická fakulta UMB, 2010, 330 s. ISBN 978-80-8083-806-5.

2. Klátik, J. 2016. Kontrola výkonu rozhodnutí technickými prostriedkami / Checking the technical means of enforcement. In Visegrad Journal on Human Rights, roč. 4, 2016, číslo 2. ISSN 1339-7915, s. 13 - 20.

3. Mašlanyová, D. et al. 2016. Trestné právo hmotné. Všeobecná a osobitná čast'. 2. doplnené a prepracované vydanie. Plzeň : Vydavatelství a nakladatelství Aleš Čeněk, 2016, 624 s., ISBN 978-80-7380-618-7.

4. Zákona č. 575/2001 Z. z. o organizácii činnosti vlády a organizácii ústrednej štátnej správy.

5. Zákon č. 275/2006 Z. z. o informačných systémoch verejnej správy.

6. Zákon č. 300/2005 Z. z. Trestný zákon v znení neskorších noviel.

7. Zákon č. 305/2013 Z. z. o elektronickej podobe výkonu pôsobnosti orgánov verejnej moci a o zmene a doplnení niektorých zákonov (zákon o e-Governmente).

8. Zákon č. 78/2015 Z. z. o kontrole výkonu niektorých rozhodnutí technickými prostriedkami a o zmene a doplnení niektorých zákonov.

9. Zákon č. 160/2015 Z. z. Civilný sporový poriadok v znení neskorších predpisov 